\title{
Characterization of long-term care facilities for the elderly in the metropolitan region of Belo Horizonte
}

Tatiana Teixeira Barral de Lacerda' Natália de Cássia Horta²

Marina Celly Martins Ribeiro de Souza ${ }^{3}$ Tatiana Resende Prado Rangel de Oliveira ${ }^{4}$ Karla Geovani Silva Marcelino ${ }^{5}$ Quesia Nayrane Ferreira ${ }^{5}$

\section{Abstract}

Objective: to characterize Long Term Care Facilities for the Elderly (LTCFs) from the Metropolitan Region of Belo Horizonte, Minas Gerais, Brazil in terms of administrative and care aspects. Method: an exploratory, quantitative study was conducted in the $\mathrm{MRBH}$, with primary and secondary sources used to map the LTCFs. A structured questionnaire was used for characterization, and data was collected between November 2014 and December 2015 through telephone contact and site visits to the LTCFs. A descriptive statistical analysis of the data was subsequently performed. Results: the 156 participating institutions included private and mixed institutions, with predominantly female residents with dependency levels I and II, and elevated levels of occupation. Philanthropic LTCFs directly receive the retirement pensions of the elderly persons, although most also receive a government grant. The results in terms of activities offered were similar for the philanthropic and private facilities, while the staff of the private facilities had more health professionals and the philanthropic facilities had more social workers and psychologists. Conclusions: there was significant participation among the LTCFs, despite the limiting factors of the study such as the data collection instrument and strategy. It is important to prioritize the elderly when creating policies to improve care for institutionalized individuals, as well as facilitating interlocution between LTCFs to minimize the abandonment of state participation.

1 Pontifícia Universidade Católica de Minas Gerais (PUC-MG), Instituto de Ciências Biológicas e de Saúde, Departamento de Fisioterapia. Betim, MG, Brasil.

2 Pontifícia Universidade Católica de Minas Gerais (PUC-MG), Instituto de Ciências Biológicas e de Saúde, Departamento de Enfermagem. Belo Horizonte, MG, Brasil.

3 The College of New Jersey, Department of Public Health, School of Nursing, Health and Exercise Science. New Jersey, USA.

4 Pontifícia Universidade Católica de Minas Gerais (PUC-MG), Instituto de Ciências Biológicas e de Saúde, Departamento de Nutrição. Belo Horizonte, MG, Brasil.

5 Pontifícia Universidade Católica de Minas Gerais (PUC-MG), Escola de Enfermagem, Núcleo de Pesquisa Processos Heurísticos e Assistenciais em Saúde e Enfermagem (PHASE).

Research financed by the Conselho Nacional de Desenvolvimento Científico e Tecnológico, CNPq, under Universal Application Process no 456804/2014-5; Validity approved: November 2014 / October 2017, by the Programa Institucional de Bolsas de Iniciação Científica (PIBIC) PUC Minas and the Fundo de Incentivo a Pesquisa (FIP).

Correspondence

Tatiana Teixeira Barral de Lacerda

E-mail: tatiana.barral@yahoo.com.br
Keywords: Elderly. Homes for the Aged. Aging. Health of the Elderly. 


\section{INTRODUCTION}

Brazil is undergoing a period of demographic transition and population aging due to a reduction in the birth rate and a decrease in the mortality rate ${ }^{1}$. In a decade, the proportion of elderly persons rose from $9.7 \%$ in 2004 to $13.7 \%$ in $2014^{2}$, and projections indicate this group will represent $18.6 \%$ of the population in 2030 and $33.7 \%$ in $2060^{3}$. Data from the National Household Samples Survey showed that the population of elderly people in Brazil reached more than 27.8 million in $2014^{4}$. Therefore, the country faces a situation of complex and costly diseases, typical of long-lived countries characterized by chronic illnesses ${ }^{5}$.

Due to social changes and issues, coupled with the increase in the number of elderly people, the demand for facilities that provide care for this population has been growing steadily. This phenomenon depends on cultural factors, the degree of family support and the availability of alternative services. While Brazilian legislation recommends that care should be provided by the family, many families do not have the financial conditions or time to care for their elderly relatives, and Long-Term Care Facilities for the Elderly (LTCFs) are an alternative to preserve the lives of these individuals ${ }^{6}$. Long-term care for the elderly, however, is considered a major gap in public policies, whether in the health sector or in social policies? ${ }^{7}$ LTCFs should be one of the links in the network of care for the elderly and the result of public policy, but instead there is a certain disregard for this issue ${ }^{8}$.

In 2008, the Institute of Applied Economic Research ${ }^{1}$ carried out a national survey of the population of elderly people living in LTCFs and identified 683 facilities in the state of Minas Gerais (MG), distributed in 476 of the 853 municipal regions, which house around $1 \%$ of the elderly population of Minas Gerais?. The lack of studies that outline the profile of LTCFs in Brazil reinforces the need to broaden such research due to the growing increase in such facilities, linked to the lack of political support and also the interest in society in issues related to aging, either due to the scale of the market or future projections regarding the living process. In the Metropolitan Region of Belo Horizonte (MRBH), there is a shortage of reliable sources for the recovery of LTCF data, emphasizing the importance of studies in this area. Thus, the present study aims to characterize the administrative and care aspects of LTCFs in the MRBH.

\section{METHOD}

A descriptive-exploratory study with a quantitative approach was performed, based on the 34 municipalities of the Metropolitan Region of Belo Horizonte (MRBH) in Minas Gerais. This is the third largest urban agglomeration in Brazil, with approximately 5.4 million inhabitants. In this study, 22 of the total number of municipal regions were included, being those with one or more LTCF: Belo Horizonte (BH), Betim, Brumadinho, Caeté, Contagem, Esmeraldas, Florestal, Ibirité, Igarapé, Itaguara, Jaboticatubas, Lagoa Santa, Mateus Leme, Matozinhos, Nova Lima, Pedro Leopoldo, Ribeirão das Neves, Sabará, Santa Luzia, São Joaquim de Bicas, São José da Lapa and Vespasiano.

The following primary sources were used to survey the LTCFs: the Federal Public Ministry, the State Health Department of Minas Gerais, the Municipal Health Department and the Municipal Public Ministry of Belo Horizonte, as this municipal region has the largest number of facilities. Secondary sources such as booklets, websites and social networks were also used. In this manner, 231 LTCFs were identified and, after the sources were cross-referenced, the existence of 170 LTCFs in the MRBH was confirmed. It should be emphasized that LTCFs without records or operating permits were not included in this study. The difference between the 231 LTCFs identified and the 170 facilities confirmed is therefore due to the existence of duplicate data or the closure of the activities of some facilities.

A structured questionnaire created by the authors was used for data collection. This allowed a profile of the researched facilities to be identified, such as type, number of residents, criteria for admission of residents, among others. Data collection involved initial telephone contact with an on-site visit carried out in facilities where telephone contact was not possible. Collection occurred between November 2014 and December 2015 and a database was created from the findings. Descriptive statistics were used to analyze the data and the results were presented, in terms of distribution frequency, in tables and graphs. 
The study was approved by the Ethics Research Committee of PUC Minas under opinion number 817 (CAAE: 31471114.4.0000.5137), and the participating facilities signed forms agreeing to participate.

\section{RESULTS}

A total of 170 institutions were surveyed, 156 of which participated in the survey with the consent of their managers, who were mostly the administrator/ owner or director of the institution (47.44\%), or the technical manager, manager or coordinator (23.97\%), In the absence of primary contacts, the administrative and/or health professionals of the facilities $(28.59 \%)$ were interviewed. Table 1 shows the number of LTCFs mapped and the participants with type and total of institutionalized elderly residents by municipal region.

Table 1. Distribution of Long Term Care Facilities for Elderly Persons in the Metropolitan Region of Belo Horizonte, Minas Gerais, 2015

\begin{tabular}{|c|c|c|c|c|c|}
\hline Municipal Regions & $\begin{array}{l}\text { Number } \\
\text { of LTCFs } \\
\text { mapped }\end{array}$ & $\begin{array}{l}\text { Number of } \\
\text { participating } \\
\text { LTCFs }\end{array}$ & $\begin{array}{l}\text { Number } \\
\text { of private } \\
\text { participating } \\
\text { LTCFs }\end{array}$ & $\begin{array}{l}\text { Number of } \\
\text { philanthropic } \\
\text { participating } \\
\text { LTCFs }\end{array}$ & $\begin{array}{l}\text { Total number } \\
\text { of residents in } \\
\text { participating } \\
\text { LTCFs }\end{array}$ \\
\hline Belo Horizonte & 118 & 106 & 79 & 27 & 2438 \\
\hline Betim & 3 & 3 & 0 & 3 & 108 \\
\hline Brumadinho & 1 & 1 & 0 & 1 & 63 \\
\hline Caeté & 2 & 2 & 0 & 2 & 79 \\
\hline Contagem & 15 & 15 & 11 & 4 & 337 \\
\hline Esmeraldas & 1 & 1 & 0 & 1 & 26 \\
\hline Florestal & 1 & 1 & 0 & 1 & 16 \\
\hline Ibirité & 2 & 2 & 0 & 2 & 35 \\
\hline Igarapé & 1 & 1 & 0 & 1 & 32 \\
\hline Itaguara & 1 & 0 & 0 & 0 & - \\
\hline Jaboticatubas & 1 & 1 & 0 & 1 & 22 \\
\hline Lagoa Santa & 3 & 3 & 1 & 2 & 112 \\
\hline Mateus Leme & 1 & 1 & 0 & 1 & 33 \\
\hline Matozinhos & 1 & 1 & 0 & 1 & 24 \\
\hline Nova Lima & 1 & 1 & 0 & 1 & 36 \\
\hline Pedro Leopoldo & 1 & 0 & 0 & 0 & - \\
\hline Ribeirão das Neves & 5 & 5 & 2 & 3 & 121 \\
\hline Sabará & 2 & 2 & 0 & 2 & 43 \\
\hline Santa Luzia & 7 & 7 & 3 & 4 & 170 \\
\hline São Joaquim de Bicas & 1 & 1 & 0 & 1 & 12 \\
\hline São José da Lapa & 1 & 1 & 0 & 1 & 12 \\
\hline Vespasiano & 1 & 1 & & 1 & 33 \\
\hline Total & 170 & 156 & 96 & 60 & 3752 \\
\hline
\end{tabular}


Of the 156 participating institutions, $62 \%$ were private (96) and 38\% (60) were philanthropic. Private non-profit entities that provide social care services are considered philanthropic, certified by the National Council of Social Assistance (CNAS) ${ }^{10}$. The philanthropic facilities were located in all the municipal regions mapped, with the emphasis on 12 municipal regions with smaller populations and only one philanthropic institution, as shown in Table 1. The highest concentration of LTCFs was in the state capital, Belo Horizonte, with 118 facilities mapped, most of which were private (106 participants, 79 private and 27 philanthropic).

The survey revealed an average occupancy rate of $88 \%$, regardless of the nature of the institution. Regarding the capacity of institutions, philanthropic facilities operated at $95 \%$ of capacity, and private facilities at $82 \%$. Of the participating facilities, 67 $(42.9 \%)$ stated that they had at least one criterion for non-admission of the elderly; 39 (25\%) two criteria; $32(20.5 \%)$ three or more criteria and only 18 (11.6\%) said they had no criteria. Among the criteria most frequently described by facilities for non-admission of the elderly were degree of dependency $(18.9 \%)$ and the presence of psychiatric disorders (13.8\%). Being bedridden, tracheostomized, having dementia or an infectious-contagious disease are other examples that may prevent the admission of the elderly to the LTCFs surveyed. A total of $77 \%$ of the LTCFs were mixed; $20 \%$ were exclusively female and $3 \%$ male. Women corresponded to $67 \%$ of the institutionalized public. It should be noted that this information corresponds to $88.4 \%$ of the gender data of the residents of the participating institutions; $11.6 \%$ of LTCFs were not included as the interviewee was unable to provide the information.

Information relating to the degree of dependency of the institutionalized elderly person was not provided by $41.8 \%$ (1.568) of the sample. This is because at the time of the interview the respondents were not in possession of this information. Of the 2,184 who provided answers, 874 elderly persons had grade II dependency, 677 had grade I and 633 had grade III. (Figure 1).

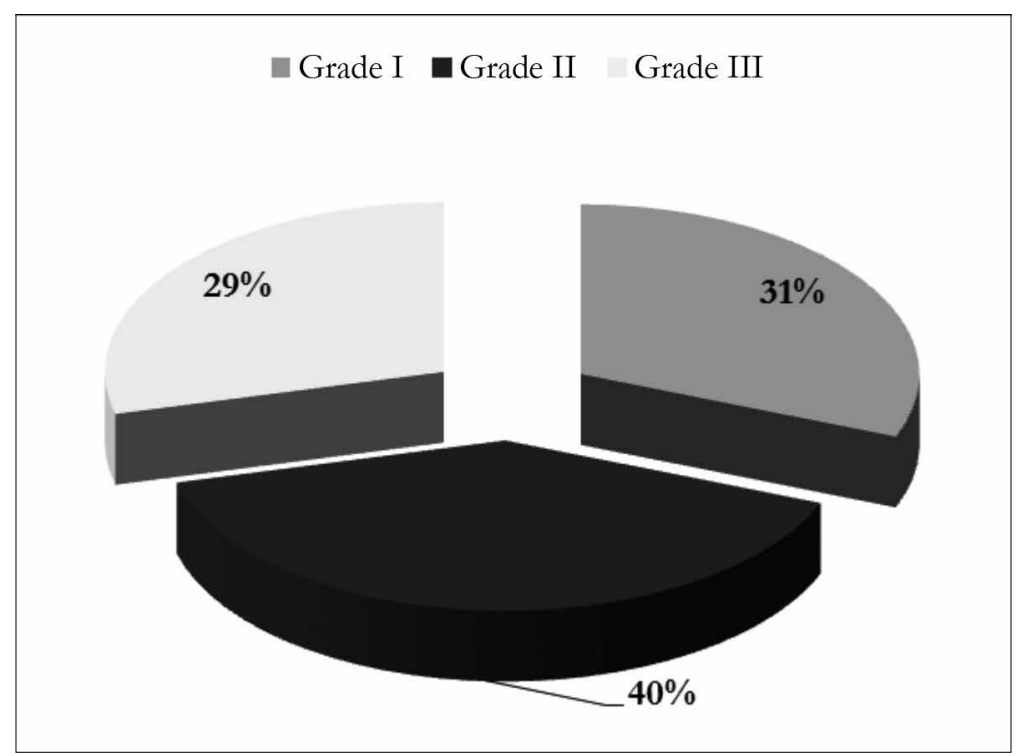

Figure 1. Proportion of institutionalized elderly persons according to degree of dependency. Metropolitan Region of Belo Horizonte, Minas Gerais, 2014 to 2015. 
The majority of private LTCFs (90.6\%), declared that they did not use the pensions of the elderly persons to fund the institution; whereas the majority of philanthropic facilities (93.3\%), used the benefits of the elderly person to cover costs. Of these, $79 \%$ used up to $70 \%$, and $20 \%$ used more than $70 \%$ of the monthly income of the elderly person. Only 63\% of the philanthropic LTCFs that participated in the survey said that they received government grants, $92.1 \%$ of which were municipal grants. The survey found that $28.1 \%$ of private LTCFs charged between three and four minimum monthly salaries (based on a minimum monthly salary of $\mathrm{R} \$ 724.00$ in 2014 and $\mathrm{R} \$ 78800$ in 2015), and 31.3\% charged over four minimum salaries. In terms of the partnerships and donations received by the LTCFs, the philanthropic facilities had more partnerships (81.7\%) and received more donations $(95.0 \%)$ than the private facilities. Of the private LTCFs $22.9 \%$ had some kind of partnership, whether with teaching institutions or several types of voluntary groups, and $17.7 \%$ received donations. A total of $16 \%$ of the LTCFs had partnerships with Higher Education Institutions, irrespective of the type of facility.

Figure 2 shows the key professionals that comprise the staff of each LTCF, followed by the type of facility. In general, it can be seen that the private LTCFs have greater numbers of health professionals, while there were more social workers and psychologists in the philanthropic facilities, due to the requirements of the contracts entered into with certain city or town councils.

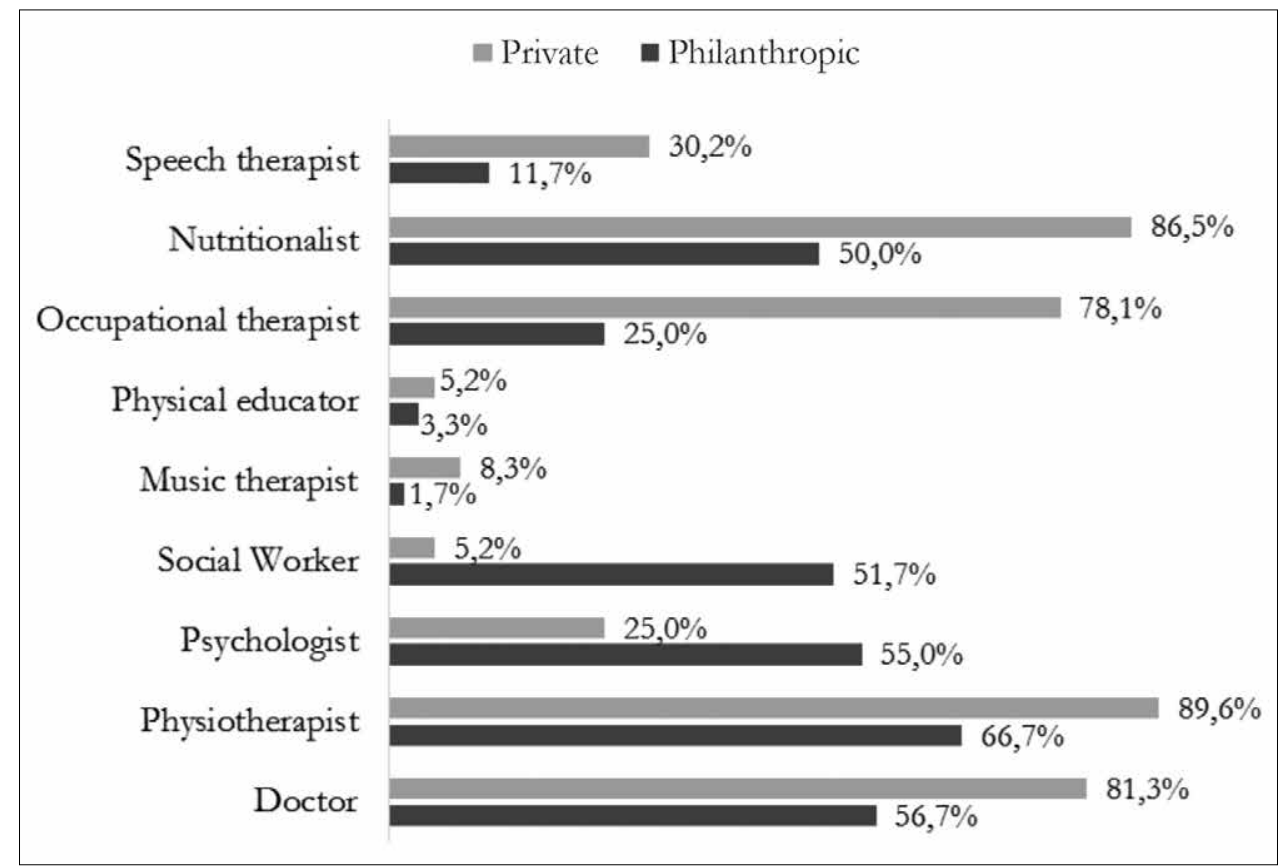

Figure 2. Composition of staff according to nature of Long Term Care Facility for the Elderly. Metropolitan Region of Belo Horizonte, Minas Gerais, 2014 to 2015.

Private and philanthropic LTCFs offered similar activities, with particular emphasis on ecumenical services, socializing parties and cooking workshops. The day-center modality is offered by 67 facilities $(43 \%)$ although less than $8 \%$ of philanthropic facilities offered this service.
Regarding the care of residents with more complex health needs, if beyond the capacity of the LTCF team, regardless of the nature of the facility, $26.4 \%$ said that individuals were cared for exclusively by the private healthcare service. A total of $73 \%$ were cared for through a mixed structure, that is, 
both public and private health services, and $0.6 \%$ were unable to provide this information. In private facilities, $25 \%$ of residents were cared for by the public service, $31.25 \%$ by the private service and $43.75 \%$ received care through a mixed structure. For residents of philanthropic facilities this proportion was different, with $43.3 \%$ receiving care from the public service, $18.3 \%$ via private healthcare and $36.7 \%$ through a mixed structure.

\section{DISCUSSION}

The data of the present study revealed the existence of 170 LTCFs in the MRBH, contrasting with a survey published in $2011^{11}$ which identified 105 facilities, notably in $\mathrm{BH}$, which had 42 private and 26 philanthropic facilities, giving a total of 68 LTCFs. These data demonstrate the accelerated growth of LTCFs, especially in the private sector and most notably in the capital of Minas Gerais, which corresponded to $74.5 \%$ of the total. A study of LTCFs in the state of Rio de Janeiro between 2010 and 2013 showed that $76.2 \%$ of the facilities were private, $21.3 \%$ were philanthropic and only $2.5 \%$ were public $^{12}$. These data agree with national studies and reinforce the change in the profile of institutions, with a tendency towards the growth of the number of private facilities in large urban centers ${ }^{1}$.

This expansion reveals the niche in the market in relation to aging, which corroborates the emerging need of families to provide care for elderly persons in the context of changes in family dynamics. However, in view of the socioeconomic conditions in Brazil, the need for vacancies in philanthropic LTCFs is important to meet the demands of social and health inequalities and inequities that can impact the institutionalization of the elderly. It should be noted that in the present study, no public LTCFs were identified, revealing irresponsibility and omission on the part of the government when dealing with an express need for social protection mechanisms, as the State should share responsibility for the care of the elderly with families and society ${ }^{13}$.

Despite the increase in LTCFs, attention should be paid to the occupation rate and the rigid admission criteria in some facilities. With regard to the occupation rate, philanthropic LTCFs operate at close to maximum capacity and even have a waiting list. This difference is probably due to the historical and social structures that surround its origin, the socioeconomic conditions of the substantial majority of the Brazilian elderly, and the scarcity of public policies of care for this population which means no other form of care is available. Despite the significant increase of private facilities in recent years from a market perspective, similar surveys showed occupancy rates of $91.6 \%$ and $91.5 \% \%^{1,12}$, suggesting that the difficulty of access may limit decisions regarding institutionalization. This hypothesis is reinforced by strict criteria for admission to most $\mathrm{LTCFs}^{14}$, although current legislation recommends only age as a criterion, regardless of family support, for residing in $\mathrm{LTCFs}^{15}$. There still seems to be a preference for independent older people, as they are less costly and require less care, with most philanthropic facilities not admitting elderly people with dementia, who are bedridden or who have organic diseases ${ }^{14}$. The degree of dependency and the presence of dementia and some illnesses, such as infectious diseases, were the conditions that most influenced non-admission to the LTCF ${ }^{11}$.

A previous study conducted by Camargos et al. on the demand for LTCF vacancies in the MRBH, showed that there is a waiting list for admission in around $60 \%$ of facilities ${ }^{11}$. This list allows institutions to reinforce the choice of "desired elderly persons", or in other words, more independent individuals, to the detriment of those in worse conditions of health, placing the social duty to support such elderly persons exclusively on their families. The difficulty of institutionalizing the most impaired elderly persons shows the need for discussion about frailty and public policies aimed at this population group, and points to the inability of the State to meet this demand ${ }^{16}$.

\section{Gender}

IBGE data from $2013^{17}$ show that women represent $55.7 \%$ of the elderly population of Brazil. However, it can be affirmed that the proportion of institutionalized women is even greater, as they are more likely to be widowed and disadvantaged 
socioeconomically ${ }^{18,19}$. Women are also in the majority on waiting lists for institutionalization, reflecting cultural aspects and family arrangements ${ }^{20}$. According to national data, $57.3 \%$ of institutionalized people in Brazil are women ${ }^{1}$. This scenario reflects a worldwide trend, based on a study by Schneider et al. in the city of New York, USA, where the population living in LTCFs (Seniors Centers) in 2009 was predominantly female $(71 \%)^{21}$. This is explained by lower mortality rates among women, corroborated by the fact that the majority of the elderly population is female, a percentage that increases gradually with age $^{15}$, characterizing the phenomenon described as "the feminization of old age"22.

\section{Level of dependency}

In this study a prevalence of elderly people with grade II dependency was observed. It is believed that the type and frequency of activities offered may influence the functionality of the elderly. A study conducted in Porto Alegre with 55 elderly persons showed that the most frequent activities among the residents were watching TV $(60 \%)$, talking with friends (54.5\%) and reading (47.3\%), meaning they remained physically inactive most of the time. Only $15(27.3 \%)$ individuals performed some physical activity ${ }^{23}$. It is important to emphasize the importance of encouraging the institutionalized elderly to participate in different activities, especially those that promote mobility and balance, which are basic assumptions for functional independence ${ }^{24}$.

A survey in the city of Taubate identified that $37 \%$ of the institutionalized elderly were considered independent for Activities of Daily Living (ADL). These results highlight the need to encourage the elderly in the institutional environment with individualized plans that provide self-care and independence, indicating the close relationship between the degree of dependency and the actions offered in the $\mathrm{LTCFs}^{25}$. It was observed that, in practice, the great challenge for the promotion of health seems to be the difficulty of the facilities to adapt the actions they offer to the heterogeneity of residents, with respect to degree of dependency and cognitive capacity.

\section{Cost and established partners}

While it is advocated that the contribution of the elderly to the cost of care in a philanthropic entity should be optional and should not exceed $70 \%$ of monthly income ${ }^{13}$, a fifth of the philanthropic-based LTCFs claimed to take a higher percentage.

A study carried out between 2006 and 2007 in LTCFs in the state of Paraná revealed that the facilities depended on the amounts paid by residents and/or their relatives, which represented $64 \%$ of their total income ${ }^{26}$. In a national survey conducted between 2007 and 2009, only 6.6\% of Brazilian institutions were public or mixed ${ }^{1}$; showing that care for the elderly is still the responsibility of the elderly persons themselves and their families. It is necessary to develop forms of long-term care by the State, beyond simple co-financing through an agreement signed by the municipal region with philanthropic facilities. This paradox is described by Giacomin (2012) ${ }^{8}$, when revealing that the Brazilian State transfers its responsibility in the care of the institutionalized elderly to philanthropic LTCFs, since the number of public facilities is insignificant. This outsourcing of state care to philanthropic LTCFs violates the provisions of the National Social Assistance Policy (PNAS), considering the universal policy of allowing the collection of a substantial portion of the benefits of the elderly persons.

The fact that most of the revenue that comes from government grants in the case of philanthropic LTCFs is derived from municipal resources can be explained by the organization of PNAS through the Unified System of Social Care (SUAS), which advocates the decentralization of the level of complexity. Thus, the federal government transfers resources to municipal funds through agreements signed with municipal regions.

Despite the growing increase in private LTCFs, the prohibitive costs charged makes such facilities an option for few elderly persons, considering the incomes received by the majority of retirees ${ }^{27}$.

It was expected that philanthropic LTCFs would form more partnerships and receive more donations, as was shown in the study, since it is known that 
they receive little help from public authorities, and require community and resident resources for their upkeep. Corroborating with the findings of this study, there were almost two volunteers (1.80) per elderly person in the philanthropic LTCFs, and the government contributed $12 \%$ of the expenses through signed contracts ${ }^{27}$. The history of asylums or shelters in Brazil is still marked by the participation of the church (Saint Vincent de Paul Society) and by the philanthropy that guarantees institutions tax exemptions and an increased chance of receiving donations and voluntary staff and/or staff granted by the State ${ }^{1}$.

A study conducted between 2006 and 2009 showed that philanthropic facilities in the northeast of Brazil established a wider range of partnerships than public and private facilities ${ }^{28}$. Although public funding is largely insignificant, the State contributes in other ways through partnerships, such as the provision of medicines and medical services. Some State action is also present in the private sector, including partnerships with the Unified Health System (SUS), as well as with religious associations and universities, with the latter taking the form of supervised internships ${ }^{1}$.

The presence of students in LTCFs is significant given the importance of these future elderly care workers, preparing them and making them aware of gerontological issues, contributing to the improvement of the care provided and, above all, to the renewal of the practice through studies and research ${ }^{29}$. The partnership with Higher Education Institutions occurs in more than $10 \%$ of public and philanthropic LTCFs, according to a study of all the regions of $\mathrm{Brazi}^{30}$. An international study conducted in Portland in the USA found that the strengthening of organizational ties with the community and teaching brings benefits for both sides through the sharing of resources ${ }^{31}$.

\section{Staff and activities offered}

Despite not being health institutions, the majority of services offered in LTCFs relate to healthcare, with $66.1 \%$ providing medical services and $56 \%$ physiotherapy services ${ }^{1}$. It is important to discuss this trend, particularly in private facilities, which is moving towards the transformation of LTCFs into "mini hospitals" and raises a necessary question about the overload of activities and the lack of connection of these professionals with the elderly. This may be a strategy adopted by these facilities to "sell" their product, since relatives and those responsible for the elderly persons tend to assume that their family members will be better cared for in such facilities. On the other hand, philanthropic LTCFs have more psychologists and social workers than private facilities, demonstrating their historical role as social assistance institutions. The largest expenses for most LTCFs were human resources (54\%), followed by food (17\%) and building maintenance (11\%). ${ }^{26}$.

It should be emphasized that LTCFs can be seen not only as social care entities, but as a hybrid service in the provision of care that includes Activities of Daily Living (ADL), health care and a social and emotional life ${ }^{31,32}$. However, RDC 283/2005 $5^{15}$ does not establish the number of graduate-level professionals who should make up the staff of a LTCF; but determines that for every 40 elderly people, there must be one graduate-level professional, with a workload of 12 hours per week, to carry out leisure activities, and that there should be a technical manager (TM), also with degree level training, with minimum working hours of 20 hours per week.

In relation to the activities offered, contrary to what might be expected, it was observed that philanthropic LTCFs offer several activities, despite their difficulties in terms of specific physical structures like libraries and academies, which are more frequent in private LTCFs.

Despite being present in less than half of the LTCFs surveyed, the day-center modality is an alternative that allows the maintenance of family ties and generates lower costs. This represents a space for elderly people who do not have full-time care at home ${ }^{28}$. However, what is observed is that this service is almost exclusively offered by private LTCFs, and is not an option for lower income and, therefore, more vulnerable, families. In addition, one should consider the particularities of the day-center, which are different in nature from LTCFs. 


\section{Complex health needs}

The creation and implementation of actions and services with inter and intra-sectorial linkage between all segments of society envisaged by the National Policy on the Elderly (1994) ${ }^{33}$, faces operationalization and implementation challenges, especially considering the relationship between LTCFs and the Health System ${ }^{31,34}$. The (Unified Health System or National Health Service) SUS is the main place of care for institutionalized elderly persons $(61.9 \%)$, through basic health units and SAMU $^{11,23}$. In philanthropic LTCFs, most elderly persons do not have a health plan ${ }^{35}$. It is believed that the $73 \%$ who use both public and private services in this study, use private services in a complementary manner, obtaining medicines and vaccines through Primary Health Care, as these are not provided by private health services. Home healthcare services for elderly persons with supplementary health insurance was also identified.

\section{Difficulties and limitations of the present study}

The great difficulties found when carrying out the survey of LTCFs in the MRBH must be noted. It was necessary to perform a search of several sources, as none presented complete and updated data. This reveals, in part, the lack of knowledge/inability of the organs responsible for the public management of these services, especially in the context of the accelerated demographic and epidemiological transition experienced. On the other hand, one cannot disregard the lability of the economic market, as many private facilities open and/or close their doors with impressive speed.

One limitation inherent to the study is the data collection strategy used, as on-site visits were not carried out for all the facilities surveyed. There was also some variation in the respondents, as direct contact with the managers or technical managers was not always possible, and in some situations the questionnaire was carried out with another professional from the institution, thus not guaranteeing the accuracy of the data provided. In addition, for information such as degree of dependency, some interviewees responded and others did not, meaning these data may be subject to memory bias.

\section{CONCLUSIONS}

It can be concluded that the LTCFs in the MRBH are mixed in nature, with a predominance of female residents and private facilities and institutions that operate at elevated levels of occupation. Among the institutionalized elderly, most have degree of dependency I or II. The philanthropic facilities directly use the retirement pensions of the elderly for funding, although most also receive a government grant. With regard to the activities offered, it was observed that there was a diversity of actions, with ecumenical services, socialization parties and cooking workshops predominating.

There is an urgent need to prioritize the elderly in policy-making and the mobilization of councils regarding the quality of services and the establishing of intersectoral guidelines that can improve care for institutionalized elderly persons. In addition, very little is done by the government to meet the specific demands of care for the institutionalized elderly. Such problems could often be minimized by greater interlocution between facilities, in order to find solutions to the problems faced and to share and expand successful experiences, highlighting the importance of the mobilization of social capital where there is little State action.

Finally, we suggest urgent further studies in this context, which will allow a better understanding of the approach to health promotion and quality of life among the institutionalized elderly. 


\section{REFERENCES}

1. Camarano AA, Kanso S, Mello JL, Carvalho DF. As instituições de longa permanência para idosos no Brasil. Camarano AA. Cuidados de longa duração para a população idosa: um novo risco social a ser assumido? Rio de Janeiro: IPEA; 2010. p.187-212.

2. Instituto Brasileiro de Geografia e Estatística. Pesquisa Nacional por Amostra de Domicílios: síntese de indicadores 2014 [Internet]. Rio de Janeiro: IBGE; 2015 [acesso em 17 set. 2016]. Disponível em: http:// biblioteca.ibge.gov.br/visualizacao/livros/liv94935.pdf

3. Instituto Brasileiro de Geografia e Estatística. Síntese de indicadores sociais: uma análise das condições de vida da população brasileira 2015 [Internet]. Rio de Janeiro: IBGE; 2015 [acesso em 17 set. 2016]. (Estudos e pesquisas. Informação demográfica e socioeconômica, n. 35). Disponível em: http:// biblioteca.ibge.gov.br/visualizacao/livros/liv95011.pdf

4. Instituto Brasileiro de Geografia e Estatística. Projeção da população do Brasil por sexo e idade para o período 2000-2060 [Internet]. Rio de Janeiro: IBGE; 2013 [acesso em 17 set. 2016]. Disponível em: http://www.ibge.gov.br/home/ estatistica/populacao/projecao_da_populacao/2013/ default.shtm

5. Barreto MS, Carreira L, Marcon SS. Envelhecimento populacional e doenças crônicas: reflexões sobre os desafios para o Sistema de Saúde Pública. Rev Kairós [Internet]. 2015 [acesso em 22 set. 2016];18(1):325-39. Disponível em: revistas.pucsp.br/index.php/kairos/ article/download/26092/18731

6. Piuvezam G, Lima K, Carvalho MS, Xavier V, Silva RA, Dantas ARF, et al. Atenção primária à saúde e os idosos institucionalizados: a perspectiva da gestão municipal no Brasil. Rev Port Saúde Pública [Internet]. 2016 [acesso em 22 set. 2016];34(1):92100. Disponível em: http://www.scielo.mec. pt/scielo.php?script $=$ sci_arttext\&pid $=\mathrm{S} 0870$ 90252016000100013\&lng=pt

7. Veras RP. Experiências e tendências internacionais de modelos de cuidado para com o idoso. Ciênc Saúde Coletiva [Internet]. 2012 [acesso em 22 set. 2016];17(1):231-8. Disponível em: http://www. scielo.br/scielo.php?script $=$ sci_arttext\&pid=S1413$81232012000100025 \& \operatorname{lng}=$ en

8. Giacomin KC. Envelhecimento populacional e os desafios para as políticas públicas. In: Berzins MV, Borges MC, organizadores. Políticas públicas para um país que envelhece. São Paulo: Martinari; 2012. p. 14-44.

9. Camarano AA, coordenadora. Características das instituições de longa permanência para idosos: Região Sudeste. Brasília, DF: IPEA; 2010.
10. Brasil. Lei n. ${ }^{\circ} 8.742$, de 7 de dezembro de 1993. Dispõe sobre a organização da Assistência Social e dá outras providências. Diário Oficial da União. 07 dez 1993.

11. Camargos MCS. Instituições de longa permanência para idosos: um estudo sobre a necessidade de vagas. Rev Bras Estud Popul [Internet]. 2014 [acesso em 22 set. 2016];31(1):211-7. Disponível em: http://www. scielo.br/scielo.php?script $=$ sci_arttext\&pid $=$ S010230982014000100012\&lng=en\&nrm=iso

12. De Paula RCC. Dimensionamento de pessoal de enfermagem em instituições de longa permanência para idosos: estudo retrospectivo [Dissertação]. Niterói: Universidade Federal Fluminence; 2016.

13. Brasil. Lei 10.741, de 01 de outubro de 2003. Dispõe sobre o Estatuto do Idoso e dá outras providências. Diário Oficial da União. 01 out. 2003:1. Disponível em: http://www.planalto.gov.br/ccivil_03/leis/2003/ 110.741.htm

14. Chaimowicz F, Greco DB. Dinâmica da institucionalização de idosos em Belo Horizonte. Rev Saúde Pública [Internet]. 1999 [acesso em 15 mar. 2013];33(5):454-60. Disponível em: http://www. scielo.br/pdf/rsp/v33n5/0630/pdf

15. Agência Nacional de Vigilância Sanitária. RDC n ${ }^{\circ}$ 283, de 26 de setembro de 2005. Regulamento técnico para o funcionamento das instituições de longa permanência para idosos. ANVISA. 2005:1-16.

16. Araújo AM, Neto TBS, Bós AJG. Diferenças no perfil de pessoas idosas institucionalizadas, em lista de espera e que não desejam institucionalização. Rev Bras Geriatr Gerontol [Internet]. 2016 [acesso em 8 set. 2017];19(1):105-18. Disponível em: http://www.scielo.br/scielo.php?pid=S1809$98232016000100105 \&$ script $=$ sci_arttext\&tlng=pt

17. Instituto Brasileiro de Geografia e Estatística. Síntese de indicadores sociais: uma análise das condições de vida da população brasileira 2013. Rio de Janeiro: IBGE; 2013.

18. Oliveira MPF, Novaes MRCG. Perfil socioeconômico, epidemiológico e farmacoterapêutico de idosos institucionalizados de Brasília, Brasil. Ciênc Saúde Coletiva [Internet]. 2013 [acesso em 08 de set. 2017];18(4):1069-78 . Disponível em: http://www. redalyc.org/articulo.oa?id=63026309023

19. Güths JFS, Jacob MHVM, Santos AMPV, Arossi GA, Béria JU. Perfil sociodemográfico, aspectos familiares, percepção de saúde, capacidade funcional e depressão em idosos institucionalizados no Litoral Norte do Rio Grande do Sul, Brasil. Rev Bras Geriatr Gerontol [Internet]. 2017 [acesso em 08 de set. 2017];20(2):175-85. Disponível em: http://www. redalyc.org/articulo.oa?id $=403851250003$ 
20. Araújo AM, Sousa NTB, Bós AJG. Differences between the profiles of institutionalized elderly people and those on waiting lists and who do not want to be institutionalized. Rev Bras Geriatr Gerontol [Internet]. 2016 [acesso em 24 set. 2016];19(1):105-18. Disponível em: http://www.scielo.br/scielo.php?script=sci_ arttext\&pid=S1809-98232016000100105\&lng=en.

21. Schneider AE, Ralph N, Olson C, Flatley AM, Thorpe L. Predictors of Senior Center Use among Older Adults in New York City Public Housing. J Urban Health. 2014;91(6):1033-47.

22. Almeida LFF, Freitas EL, Salgado SML, Gomes IS, Franceschini SCC, Ribeiro AQ. Projeto de intervenção comunitária "Em Comum-Idade": contribuições para a promoção da saúde entre idosos de Viçosa, MG, Brasil. Ciênc Saúde Coletiva [Internet]. 2015 [acesso em 22 set. 2016]; 20(12):3763-74. Disponível em: http://www. scielo.br/scielo.php?script $=$ sci_arttext\&pid $=$ S1413$81232015001203763 \& \operatorname{lng}=$ en.

23. Terra NL, Bós AJG, Bonardi G, Dickel SGF, Mohr CC, Mallmann L, et al. Diferenças biopsicossociais entre idosos de instituição asilar particular e filantrópica da cidade de Porto Alegre. Sci Med. 2009;19(1):3-10.

24. Souza CC, Valmorbida LA, Oliveira JP, Borsatto AC, Lorenzini M, Knorst MR, et al. Mobilidade funcional em idosos institucionalizados e não institucionalizados. Rev Bras Geriatr Gerontol [Internet]. 2013 [acesso em 24 set. 2016];16(2):285-93. Disponível em: http://www. scielo.br/scielo.php?script=sci_arttext\&pid $=$ S180998232013000200008\&lng=en.

25. Araújo MOPH, Ceolim MF. Avaliação do grau de independência de idosos residentes em instituições de longa permanência. Rev Esc. Enferm USP [Internet]. 2007 [acesso em 22 set. 2016];41(3):378-85. Disponível em: http://www.scielo.br/scielo.php?script $=$ sci_ arttext\&pid=S0080-62342007000300006\&lng=en.

26. Instituto Paranaense de Desenvolvimento Econômico e Social. Instituições de longa permanência para idosos: caracterização e condições de atendimento. Curitiba: IPARDES; 2008.
27. Freire FS, Mendonça LH, Costa AJB. Sustentabilidade econômica das instituições de longa permanência para idosos. Saúde debate [Internet]. 2012 [acesso em 24 set. 2016];36(95):533-43. Disponível em: http://www. scielo.br/scielo.php?script $=$ sci_arttext\&pid $=$ S0103$11042012000400005 \& \operatorname{lng}=$ en\&nrm=iso\&tlng=pt

28. Christophe M. Instituições de longa permanência para idosos no Brasil: uma opção de cuidados de longa duração? [dissertação]. Rio de Janeiro: Escola Nacional de Ciências Estatísticas; 2009.

29. Silva BT, Santos SSC. Cuidados aos idosos institucionalizados: opiniões do sujeito coletivo enfermeiro para 2026. Acta Paul Enferm. 2010;23(6):775-81.

30. Creutzberg M, Gonçalves LHT. Acoplamento entre instituições de longa permanência para idosos e universidades. Rev Eletrônica Enferm [Internet]. 2011 [acesso em 17 set. 2016];13(4):620-8. Disponível em: https://www.fen.ufg.br/revista/v13/n4/pdf/ v13n4a05.pdf

31. Cannon ML. Impacts of organizational ties for senior centers: Findings from a collective case study in Portland, Oregon. J Aging Stud. 2017;42:9-14.

32. Oliveira JR, Rocha Júnior PR. Qualidade de vida e capacidade funcional do idoso institucionalizado. Rev Kairós. 2014;17(3):343-53.

33. Brasil. Lei no 8.842, de 04 de janeiro de 1994. Dispõe sobre a Política Nacional do Idoso e dá outras providências. Diário Oficial da União. 05 jan. 1994. p. 77.

34. Piuvezam G, Lima KC, Carvalho MS, Xavier VGP, Silva RA, Dantas ARF, et al. Atenção primária à saúde e os idosos institucionalizados: a perspectiva da gestão municipal no Brasil. Rev Port Saúde Pública. 2016;34(1):92-100.

35. Pinheiro NCG, Holanda VCD, Melo LA, Medeiros AKB, Lima KC. Desigualdade no perfil dos idosos institucionalizados na cidade de Natal, Brasil. Ciênc Saúde Coletiva. 2016;21(11):3399-3405. 